\title{
Visual eWOM Usefulness and Credibility: The Antecedents and Consequences
}

\author{
Whony Rofianto \\ Indonesia Banking School \\ rofianto@ibs.ac.id \\ Desta Atasyah Kornelys \\ Indonesia Banking School \\ desta.atasyah@gmail.com \\ Muhammad Rifkhansyah \\ Indonesia Banking School \\ rifkhansyah@gmail.com
}

\begin{abstract}
Nowadays the practice of spreading and utilizing eWOM increasingly prevalent. A lot of examination on eWOM effectiveness has been done, but it is still fragmented and overlook the potential of Visual eWom (VeWOM). Departing from the electronic word-of-mouth communication framework this research attempts to provide empirical evidence on the eWOM credibility-forming aspect and its implications toward eWOM adoption rate in the context of VeWOM video "unboxing". This research was conducted by a descriptiveexplanatory approach using primary data, collected through a cross-sectional online survey. The hypothesis testing is performed by analyzing structural model estimation result through Structural Equation Modeling (SEM) approach on 105 sample data of YouTube video-sharing site viewers. The proposed structural model involves three exogenous variables and three endogenous variables. The estimation results of the structural model indicate that VeWOM argument quality has a positive impact on VeWOM usefulness. Meanwhile, communicator expertise and trustworthiness proved to encourage the formation of VeWOM credibility. On the other hand, this study also proved the positive impact of VeWOM credibility on VeWOM adoption, however, the positive effect of VeWOM usefulness on VeWOM adoption was not proven in this study
\end{abstract}

Keywords: VeWOM, usefulness, credibility, communicator credibility, VeWOM adoption

\begin{abstract}
Abstrak
Dewasa ini praktik penyebaran dan pemanfaatan eWOM semakin marak. Cukup banyak penelitian tentang efektivitas eWOM telah dilakukan, namun masih terfragmentasi dan mengesampingkan potensi dari Visual eWom (VeWOM). Berangkat dari electronic word-of-mouth communication framework penelitian ini berupaya memberikan bukti empiris akan aspek pembentuk kredibilitas eWOM dan implikasinya terhadap tingkat adopsi eWOM khususnya pada konteks VeWOM video "unboxing". Penelitian dilakukan dengan pendekatan deskriptif explanatory menggunakan data primer yang dihimpun melalui survei online secara cross-sectional. Pengujian hipotesis dilakukan melalui analisis pada hasil estimasi model struktural dengan pendekatan Structural Equation Modelling (SEM) terhadap 105 data sampel pemirsa situs videosharing YouTube. Model struktural yang diajukan melibatkan tiga variable eksogen dan tiga variable endogen. Hasil estimasi pada model struktural mengindikasikan bahwa VeWOM argument quality berdampak positif pada VeWOM usefulness. Sementara itu communicator expertise dan communicator trustworthiness terbukti mendorong pembentukan VeWOM credibility. Di sisi lain, hasil analisis pada penelitian ini juga membuktikan dampak positif VeWOM credibility terhadap VeWOM adoption, namun demikian pengaruh positif VeWOM usefulness terhadap VeWOM adoption tidak terbukti pada penelitian ini.
\end{abstract}

Kata Kunci: VeWOM, usefulness, credibility, communicator credibility, VeWOM adoption 


\section{Introduction}

The proliferation of internet-based communication media has changed the way consumers to explore information, contact to each other and how to do transaction (King, Racherla, \& Bush, 2014). Many consumers are choosing the online transaction mechanism by various device with increasing intensity as well (Mosteller, Donthu, \& Eroglu, 2014). The problems of an online transaction are the existence of a higher level of uncertainty and risk than offline transaction (Dellarocas, 2003). Electronic word-of-mouth (eWOM) as an extension of traditional word-of-mouth (WOM) comes as one of solution for that problem, making consumers takes a right and faster purchasing decision (Hennig-Thurau \& Walsh, 2004).

Nowadays it is easier for consumers to to collect information from electronic word-of-mouth because it has become common usage in a large population (Hennig-Thurau \& Walsh, 2004) with various forms and platforms, including the visual form or called as visual eWOM. (King et al., 2014). However, this would imply new problem regarding consumers' trust in the online information which relatively easy to manipulate (Pan \& Chiou, 2011). The large number and the degree of credibility of the various information have an impact on the high consumer's psychological cost in digesting electronic word-of-mouth (Lee \& Ma, 2012).

Along with the increasing number of eWOM deployment by consumers and the use of eWOM by marketers, research on the effectiveness of eWOM is rapid growth although it's still fragmented. Many research for eWOM in marketing literature, most of them discuss eWOM in the text form. Meanwhile, nowadays Visual eWOM's potential is growing even if it still didn't get much attention from researchers. From many studies about eWOM in marketing literature, most of them discuss eWOM in the text form. Meanwhile, the potential of Visual eWOM growth have had very little attention from researchers. Departing from the electronic word-of-mouth (i.e. Cheung \& Thadani, 2012) communication framework this research attempts to provide empirical evidence on the eWOM credibility-forming aspect and its implications toward eWOM adoption rate. From the context side, this study attempts to answer previous research (King el al., 2014) about the potential of visual eWOM.

\section{Theoretical Framework and Hypothesis Develop- ment}

In the context of offline media, WOM can be a spoken speech or text form on printed media. Meanwhile, in the context of online media, eWOM can be text, audio or visual forms such as picture or video. So far, research of eWOM is mostly about eWOM in the text form while the visual form (Visual eWOM) have less researcher's attention in the middle of increasing visual eWOM users. One example of visual eWOM which increasingly used is "unboxing" video that is often posted through blogs or video-sharing sites like Youtube.

According to Elaboration Likelihood Model (ELM), the outline of response building process through com- munication messages can occur in two different paths. In the first path, central route, the process of reaction through the message careful evaluation, in the second path, peripheral route, the process of response based on the aspect of around message content (Petty, Cacioppo, \& Schumann, 1983). In the eWOM quality context review (Argument Quality) tends to push the process through central route in the formation of message's response (Cheung \& Thadani, 2012). The higher quality of information or argumentation will be perceived, the more useful for information receivers (Cheung, Lee, \& Rabjohn, 2008). The higher of message argument quality, the higher usefulness of information from the information receivers point of view (Cheung et al., 2008; Sussman \& Siegal, 2003). That explanation can apply to the eWOM visual context. Based on the statement, hypotheses are proposed as follows:

\section{H1 : VeWOM argument quality has a positive impact on VeWOM usefulness.}

In the opposite of argument message quality, the individual aspect which communicates by eWOM (communicator) is one of aspect which influences forming response for receiver's message through peripheral route (Cheung \& Thadani, 2012). The more credible source of a message, encourage higher eWOM credibility perception (Fan, Miao, Fang, \& Lin, 2013). Expertise and trustworthiness are the important aspects of source credibility (Ohanian, 1990). In the context of user generated video (UGV) expertise and trustworthiness are the main factors of credibility (Hautz, Füller, Hutter, \& Thürridl, 2014). Based on that argumentation, two assumptions may be raised:

\section{H2: Communicator expertise has a positive impact on VeWOM credibility}

H3: Communicator trustworthiness has a positive impact on VeWOM credibility.

Acceptance Model Technology gives an explanation that usefulness perception encourages adoption intention or technology users. In the context of eWOM, a higher perception of usefulness information will encourage to higher adoption of the information (Cheung et al., 2008). Based on the information of adoption model information usefulness in the eWOM context is believed to have a positive impact on eWOM adoption.

H4: VeWOM usefulness has a positive impact on VeWOM adoption.

Despite the credibility concept is often purposed to information source credibility. However, perceived credibility definition can be extended to the online review context as the assessment for information receiver about the reliability of an online review (Hong \& Park, 2012). Positive perception of online review credibility is proven that have an impact on reader's response and intention on the relevant online review's product and platform (Chih, Wang, Hsu, \& Huang, 2013). In the context online credibility's environment, eWOM has been proved that effects eWOM adoption rate (Fan et al., 2013). 


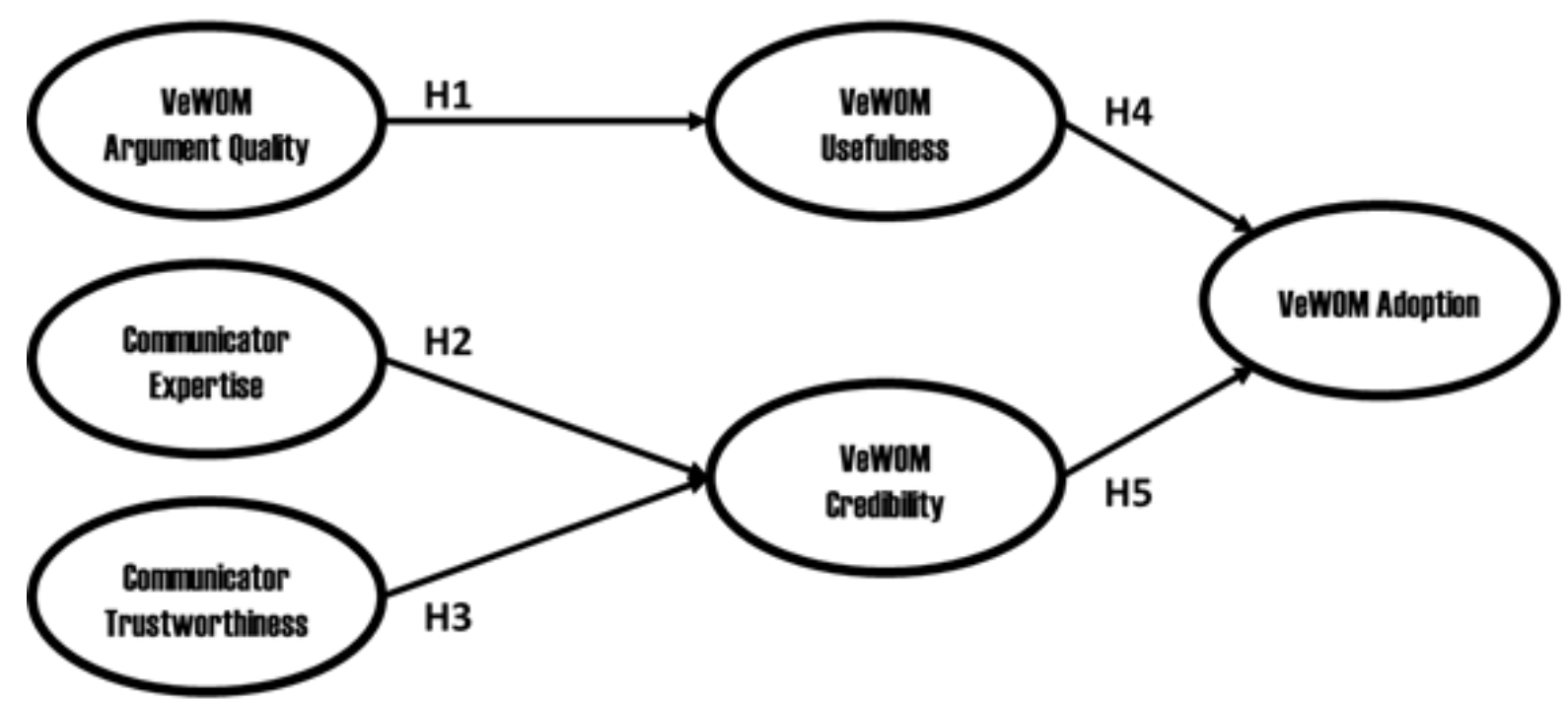

Picture 1. Research Model

H5: VeWOM credibility has a positive impact on VeWOM adoption.

\section{Research Method}

This study was conducted by a descriptive-explanatory approach which attempted to explain the relationship of observed constructs (Cooper \& Schindler, 2013). The data collected by survey techniques through an online questionnaire, which means sampling techniques can be categorized as a convenience sampling (Zikmund, Babin, Carr, \& Griffin, 2010). Data are collected from consumers sample who are viewers of Youtube video sharing sites that watching an "unboxing" video as an illustrative example to ensure that respondents can visualize the intended research context. Data collected by a cross-sectional or only collected once from each sample.

Six variables were measured using a 7-point Likert scale each variable is measured through three until four multi item scale statements adopted from previous studies. This research involved three exogenous variables and three endogenous variables that would be estimated using Structural Equation Modeling (SEM) to test the five proposed hypotheses. All indicators used as measuring tools on the questionnaire were adapted from previous studies. Overall, 21 indicators were used which means at least 105 respondent samples or five-times indicators needed. Each of six variables observed in this study was measured through indicators adopted from previous studies. The size of VeWOM argument quality and VeWOM credibility were measured by three measurement statements developed from the previous study (Cheung $\&$ Thadani, 2012). Communicator expertise and communicator trustworthiness are each measured by four and three indicators adopted from previous studies (Ohanian, 1990). VeWOM usefulness was measured by four indicators adopted from two previous studies (Edwards, Li, \& Lee, 2002; Tsang, Ho, \& Liang, 2004). Meanwhile, VeWOM adoption was measured by four statements adopted from previous studies (Shaw, 2014). The detailed explanation of questionnaire for each indicator presented in Table 1.

\section{Result, Discussion, and Managerial Implication}

The result of model estimation calculation of 105 data collected shows that the standardized loading factor's score for each indicator is above 0.7 which means indicating good validity degree for all measurement indicators used (Wijanto, 2008). The result of Average Variance Extracted (AVE) calculation from each construct shows above 0.5, which means the measurement instrument used has a good convergent validity degree. Meanwhile, the calculation result of Construct Reliability (CR) from each measuring device shows above 0.7 , which means all measurement instruments used have excellent reliability.

The result of the structural model, as illustrated in Figure 2 show that $\mathrm{p}$-value for $\mathrm{H} 1, \mathrm{H} 3$ and $\mathrm{H} 5$ lines is below of 0,001 , while $\mathrm{H} 2$ line show p-value below 0,01 and all coefficients are positive or unidirectional with the directions of previously proposed hypothesis. Thus, it can be concluded that $\mathrm{H} 1, \mathrm{H} 2, \mathrm{H} 3$ and $\mathrm{H} 5$ are supported by data. However, the estimation on $\mathrm{H} 4$ line shows p-value above 0.05 which means there is not enough evidence of empirical data collected to support the fourth hypothesis related to positive impact VeWOM usefulness on VeWOM adoption.

The test results of the first hypothesis indicate a significant positive impact on VeWOM argument quality with VeWOM usefulness from the viewer's point of view. It means, the better argument quality presented on VeWOM video unboxing it will be more useful video unboxing in the viewer's perspective. One of implication from this fact, on Youtuber's point of view (the people who creates and uploads unboxing video on the Youtube site), needs to put forward the quality aspect of message or information on the unboxing video they created if wants the viewers to have high useful perception from that video. This implication can be achieved by seeking an informative and explained adequately and convincingly. Meanwhile, marketers can take advantage of this phenomenon by finding, supporting or providing incentives to YouTubers who have good argument quality in their unboxing video as persuasive tools to the consumer. 
Table 1. Measuring Instrument

\begin{tabular}{|c|c|}
\hline Konstruk & Alat Ukur \& Sumber \\
\hline $\begin{array}{l}\text { VeWOM Argument } \\
\text { Quality }\end{array}$ & $\begin{array}{l}\text { - Pada umumnya argumentasi pada video unboxing youtuber meyakinkan } \\
\text { - Pada umumnya review video unboxing youtuber dilengkapi penjelasan yang baik } \\
\text { - Pada umumnya review video unboxing youtuber informative } \\
\text { (Cheung et al, 2012) }\end{array}$ \\
\hline $\begin{array}{l}\text { Communicator } \\
\text { Expertise }\end{array}$ & $\begin{array}{l}\text { - Pada umumnya pengulas video unboxing youtuber ahli di bidangnya } \\
\text { - Pada umumnya pengulas video unboxing youtuber berpengalaman } \\
\text { - Pada umumnya pengulas video unboxing youtuber memiliki pengetahuan di bidangnya } \\
\text { - Pada umumnya pengulas video unboxing youtuber memiliki kualifikasi yang baik } \\
\text { (Ohanian, 1990) }\end{array}$ \\
\hline $\begin{array}{l}\text { Communicator } \\
\text { Trustworthiness }\end{array}$ & $\begin{array}{l}\text { - Pada umumnya pengulas video unboxing youtuber jujur } \\
\text { - Pada umumnya pengulas video unboxing youtuber dapat diandalkan } \\
\text { - Pada umumnya pengulas video unboxing youtuber dapat dipercaya }\end{array}$ \\
\hline VeWOM Usefulness & $\begin{array}{l}\text { - Pada umumnya video unboxing youtuber memberikan informasi yang up-to-date } \\
\text { - Pada umumnya video unboxing youtuber memberikan informasi yang saya butuhkan } \\
\text { (Tsang et al., 2004) } \\
\text { - Pada umumnya video unboxing youtuber memberikan informasi yang berguna } \\
\text { - Pada umumnya video unboxing youtuber memberikan informasi yang penting } \\
\text { (Edwards et al., 2002) }\end{array}$ \\
\hline VeWOM Credibility & $\begin{array}{l}\text { - Saya rasa pada umumnya video unboxing youtuber dapat dipercaya } \\
\text { - Saya rasa pada umumnya video unboxing youtuber memberikan informasi yang sebenarnya } \\
\text { - Saya rasa pada umumnya video unboxing youtuber akurat } \\
\text { (Cheung et al, 2012) }\end{array}$ \\
\hline VeWOM Adoption & $\begin{array}{l}\text { - Saya kira video unboxing youtuber layak menjadi sarana referensi produk elektronik saya } \\
\text { - Saya berencana untuk menjadikan video unboxing youtuber sebagai referensi dalam membeli } \\
\text { produk elektronik } \\
\text { - Saya akan terlebih dahulu melihat video unboxing youtuber sebelum membeli produk elektronik } \\
\text { - Saya berencana untuk menyaksikan kembali video unboxing youtuber produk elektronik }\end{array}$ \\
\hline
\end{tabular}

The result of $\mathrm{H} 2$ and $\mathrm{H} 3$ indicate that in addition to the quality aspects of the message as probed in $\mathrm{H} 1$, the credibility of VeWOM communicator, in this case, video unboxing is an equally important aspect of VeWOM's credibility formation. As the previous concept, communicator credibility at least consists of two aspects: expertise and trustworthiness (Ohanian, 1990). This study proves that this two aspect has a significant positive impact in establishing the VeWOM credibility. As an implication of these findings, Youtuber needs to pay attention to the expertise and trustworthiness aspect of the chosen communicator if they want VeWOM's made and uploaded are credible on the viewer's point of view. Certainly, this is a condition that must be built through consistent good performance over time to hone the experience, expertise and communicator's track record. Meanwhile, the marketer's implication is there's a need to have special attention on Youtuber's credibility aspect both regarding expertise and trustworthiness if they want to be chosen as the people who do eWOM. One of the simplest parameter to identify is to see the number of viewers, subscribers and positive comment

H5 test results indicate there's a positive impact on eWOM credibility on VeWOM adoption is the level of a consumer using VeWOM in the process of making a purchasing decision. Meanwhile, the test results of $\mathrm{H} 4$ haven't been able to prove that there's a significant positive impact on VeWOM usefulness on VeWOM adoption. The two possible explanation may be an early assumption of empirical evidence is inconsistent with the first evidence. First, there's a possibility that VeWOM usefulness has no direct impact on VeWOM adoption, but it through intermediate or mediator constructs such as trust (Ogonowski, Montandon, Botha, \& Reyneke, 2014), this need a further investigation. Second, there's a possible mechanism of interaction between VeWOM usefulness with the other aspects, such as review impression (Purnawirawan, De Pelsmacker, \& Dens, 2012) that may be moderating or amplifying the positive impact of VeWOM usefulness on VeWOM adoption. Before these allegations were reviewed further this study can only conclude that VeWOM credibility is an important determinant of VeWOM adoption especially in the Youtube's unboxing video context. As an implication, if marketers want a high persuasion effect from VeWOM, the credibility of VeWOM built by the communicator's credibility is needs to be the main emphasis.

\section{Conclusion, Suggestion, and Limitations}

This research attempts to provide early empirical contribution related to the potential of VeWOM which has not received enough attention in the marketing literature in the middle of increases widespread use. These early studies have provided empirical evidence of antecedents of VeWOM usefulness and VeWOM credibility. However, this study can only prove the implications of VeWOM usefulness on VeWOM adoption partially. The further research is expected to be detailed how the relationship be- 
tween VeWOM usefulness and VeWOM adoption which has not been empirically proven in this study.

A with any other research, this study have limitations, so it needs further research to explain the phenomenon of VeWOM more comprehensively. First, this study only examines one aspect peripheral route: the credibility which reflects which the communicator and VeWOM itself. Accommodation from peripheral aspects such as aesthetic or attractiveness may be an interesting area for the further study. Second, this study has not been able to prove the direct effect of VeWOM usefulness on VeWOM adoption empirically, further study of the possibility of mediation variables such as trust or moderation like impressions or credibility may be more detail to explain that there's a more complex relationship between VeWOM usefulness with VeWOM adoption. Third, this study only tests the VeWOM phenomenon in unboxing products form, study VeWOM in other contexts such as how to use the product, product usage experience or VeWOM in the non-product context such as services or destinations may be expanded and/or explained the potential VeWOM for consumers and marketers.

\section{References}

Cheung, C. M. K., Lee, M. K. O., \& Rabjohn, N. (2008). The impact of electronic word-of-mouth. Internet Research, 18(3), 229-247.

Cheung, C. M. K., \& Thadani, D. R. (2012). The impact of electronic word-of-mouth communication: A literature analysis and integrative model. Decision Support Systems, 54(1), 461-470.

Chih, W.-H., Wang, K.-Y., Hsu, L.-C., \& Huang, S.-C. (2013). Investigating Electronic Word-of-Mouth Effects on Online Discussion Forums: The Role of Perceived Positive Electronic Word-of-Mouth Review Credibility. Cyberpsychology, Behavior, and Social Networking, 16(9), 658-668.

Cooper, D. R., \& Schindler, P. S. (2013). Business Research Methods (12th ed.). McGraw-Hill/Irwin.

Dellarocas, C. (2003). The Digitization of Word of Mouth: Promise and Challenges of Online Feedback Mechanisms. Management Science, 49(10), 14071424.

Edwards, S. M., Li, H., \& Lee, J.-H. (2002). Forced Exposure and Psychological Reactance: Antecedents and Consequences of the Perceived Intrusiveness of Pop-Up Ads. Journal of Advertising, 31(3), 83-95.

Fan, Y.-W., Miao, Y.-F., Fang, Y.-H., \& Lin, R.-Y. (2013). Establishing the Adoption of Electronic Word-ofMouth through Consumers' Perceived Credibility. International Business Research, 6(3), 58-65.

Hair, J. F., Black, W. C., Babin, B. J., \& Anderson, R. E. (2010). Multivariate Data Analysis (7th ed.). Pearson
Prentice Hall.

Hautz, J., Füller, J., Hutter, K., \& Thürridl, C. (2014). Let Users Generate Your Video Ads? The Impact of Video Source and Quality on Consumers' Perceptions and Intended Behaviors. Journal of Interactive Marketing, 28(1), 1-15.

Hennig-Thurau, T., \& Walsh, G. (2004). Electronic Word-of-Mouth: Motives for and Consequences of Reading Customer Articulations on the Internet. International Journal of Electronic Commerce, 8(2), $51-74$.

Hong, S., \& Park, H. S. (2012). Computer-mediated persuasion in online reviews: Statistical versus narrative evidence. Computers in Human Behavior, 28(3), 906-919.

King, R. A., Racherla, P., \& Bush, V. D. (2014). What We Know and Don't Know About Online Word-ofMouth: A Review and Synthesis of the Literature. Journal of Interactive Marketing, 28(3), 167-183.

Lee, H., \& Ma, Y. J. (2012). Consumer perceptions of online consumer product and service reviews and susceptibility to peer influence. Journal of Research in Interactive Marketing, 6(2), 110-132.

Mosteller, J., Donthu, N., \& Eroglu, S. (2014). The fluent online shopping experience. Journal of Business Research, 67(11), 2486-2493.

Ogonowski, A., Montandon, A., Botha, E., \& Reyneke, M. (2014). Should new online stores invest in social presence elements? The effect of social presence on initial trust formation. Journal of Retailing and Consumer Services, 21(4), 482-491. http://doi. org/10.1016/j.jretconser.2014.03.004

Ohanian, R. (1990). Construction and Validation of a Scale to Measure Celebrity Endorsers' Perceived Expertise, Trustworthiness, and Attractiveness. Journal of Advertising, 19(3), 39-52.

Pan, L.-Y., \& Chiou, J.-S. (2011). How Much Can You Trust Online Information? Cues for Perceived Trustworthiness of Consumer-generated Online Information. Journal of Interactive Marketing, 25(2), $67-74$.

Petty, R. E., Cacioppo, J. T., \& Schumann, D. (1983). Central and Peripheral Routes to Advertising Effectiveness: The Moderating Role of Involvement. Journal of Consumer Research, 10(2), 135.

Purnawirawan, N., De Pelsmacker, P., \& Dens, N. (2012). Balance and Sequence in Online Reviews: How Perceived Usefulness Affects Attitudes and Intentions. Journal of Interactive Marketing, 26(4), 244-255. http://doi.org/10.1016/j.intmar.2012.04.002

Shaw, N. (2014). The mediating influence of trust in the adoption of the mobile wallet. Journal of Retailing 
and Consumer Services, 21(4), 449-459.

Sussman, S. W., \& Siegal, W. S. (2003). Informaitonal Influence in Orgaizations: An Integrated Approach to Knowledge Adoption,. Information Systems Research, 14(1), 47-65.

Tsang, M. M., Ho, S. C., \& Liang, T.-P. (2004). Consumer Attitudes Toward Mobile Advertising: An Empirical Study. International Journal of Electronic Commerce, $8(3), 65-78$.

Venkatesh, V., \& Davis, F. D. (2000). A Theoretical Extension of the Technology Acceptance Model: Four Longitudinal Field Studies. Management Science, 46(2), 186-204.

Wijanto, S. H. (2008). Structural Equation Modeling dengan LISREL 8.8: Konsep dan Tutorial. Yogyakarta: Graha Ilmu.

Zikmund, W. G., Babin, B. J., Carr, J. C., \& Griffin, M. (2010). Business Research Methods (8th ed.). SouthWestern Cengage Learning. 